\title{
Additions to neotropical stereoid fungi (Polyporales, Basidiomycota): one new species of Lopharia and one new combination in Phlebiopsis
}

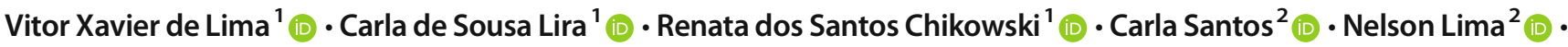 \\ Tatiana Baptista Gibertoni ${ }^{1}$ (I)
}

Received: 18 June 2019 / Revised: 21 October 2019 / Accepted: 24 October 2019

(C) German Mycological Society and Springer-Verlag GmbH Germany, part of Springer Nature 2019

\begin{abstract}
Stereoid fungi are an artificial group with mostly effused-reflexed to stipitate basidiomata, smooth hymenophore, and hyaline spores. From recent surveys in the Brazilian Atlantic Forest, Caatinga, and Cerrado, six specimens of this group had their identity tested with the nrITS and nrLSU sequences. Two of them were nested within the Lopharia s.s. clade and represent a new species L. erubescens, characterized by the dextrinoid reaction of the cystidia, and small basidia and spores. The other four were initially identified as Hjortstamia amethystea, but nested in the Phlebiopsis clade. Thus, we proposed the new combination, Phlebiopsis amethystea. We also provide keys to neotropical Lopharia s.l. and Phlebiopsis s.l. and allied species.
\end{abstract}

Keywords Brazil $\cdot$ Hjortstamia $\cdot$ Porostereum $\cdot$ Taxonomy

\section{Introduction}

Stereoid fungi are an artificial group of Basidiomycota characterized by resupinate, effused-reflexed to stipitate basidiomata, a smooth hymenial surface, and hyaline, smooth spores (Welden 2010). Also considered to be among the corticioid fungi (Bernicchia and Gorjón 2010), this group was traditionally assembled in a single genus, Stereum Hill (Burt 1920). The genus was subsequently divided based on morphological features, and with the addition of molecular techniques, the stereoid fungi were known to be distributed among several lineages of Agaricomycetes (Hibbett et al. 2014), with Stereum s.s. being in the Russulales (Miller et al. 2006).

In Welden's (2010) monograph on neotropical stereoid fungi, 13 genera were recognized, including Lopharia s.l.

Section Editor: Yu-Cheng Dai

Vitor Xavier de Lima

vitorxlima@gmail.com

1 Departamento de Micologia, Centro de Biociências, Universidade Federal de Pernambuco (UFPE), Recife, Brazil

2 CEB-Centre of Biological Engineering, Micoteca da Universidade do Minho (MUM), University of Minho, Braga, Portugal
(Polyporales) which comprises resupinate and effusedreflexed species with dimitic hyphal system, simple septate or clamped hyphae, and metuloid cystidia. Among the species included in the genus, there is L. amethystea (Hjortstam \& Ryvarden) A.L. Welden, which is a rather common species in Brazil; L. amethystea is also placed in Hjortstamia Boidin $\&$ Gilles due to the lack of clamp connections and a brownish cystidia wall (Boidin and Gilles 2002; Ryvarden 2010). Recently, the type species of Hjortstamia (H. friesii (Lév.) Boidin \& Gilles) was combined with Phlebiopsis Jülich (Phanerochaetaceae, Polyporales; Miettinen et al. 2016) based on morphology, consistent with the placement of $H$. crassa, a similar species, in the genus Phlebiopsis as a result of multigene phylogenetic analyses (Floudas and Hibbett 2015). However, morphological boundaries between Hjortstamia, Phlebiopsis (which also includes poroid species; Chen et al. 2018) and the recently described Phaeophlebiopsis Floudas \& Hibbet are unclear, and their separation is possible only at the molecular level (Floudas and Hibbett 2015). Several neotropical species of Hjortstamia have not yet been sequenced, including H. amethystea, H. mexicana (A.L. Welden) Boidin \& Gilles, and H. novae-granata (A.L. Welden) Hjortstam \& Ryvarden, and their phylogenetic affinities are still unknown.

Lopharia s.s. (Polyporaceae, Polyporales) was recently emended by Liu et al. (2018), based on a three-gene 
phylogeny and morphological analyses. The genus now includes resupinate to effused-reflexed species, with monodimitic hyphal system, clamp connections, metuloid cystidia, and large basidia. It is a widespread white-rot genus, with a limited number of species. Several Lopharia s.l. listed in Welden's monograph (2010) were combined in Porostereum Pilát (Hjortstam and Ryvarden 1990; Ryvarden 2010), but the morphological differentiation between the two genera is vague.

In the present paper, we describe one new neotropical species of Lopharia s.s. based on morphology and nrITS and nrLSU sequences phylogeny. Furthemore, we report the sequencing of $H$. amethystea specimens for the first time and describe their phylogenetic position as determined using the abovementioned genes.

\section{Material and methods}

\section{Study area}

Specimens of stereoid fungi were collected in the Amazonia (Maiandeua Island, state of Pará), Atlantic Rainforest (Biological Reserve of Pedra Talhada, state of Alagoas, and Mata do Pau-Ferro Ecological Reserve, state of Paraiba), Caatinga (Missão Velha, state of Ceará, Serra das Confusões National Park, state of Piauí, and Sítio do Carro Quebrado, state of Pernambuco), and Cerrado (RPPN/UFMS Campus, state of Mato Grosso do Sul). They were deposited at the Herbarium Padre Camille Torrend (URM) at the Universidade Federal de Pernambuco (UFPE), with duplicates in the Natural History Museum herbarium, University of Oslo (O). Exsiccatae previously deposited at URM were also studied.

\section{Morphological studies}

Macroscopic analyses were performed on fresh specimens in field condition and after drying. On dried specimens, a drop of $3 \%$ potassium hydroxide solution $(3 \% \mathrm{KOH})$ was poured over the basidioma to observe possible color changes of the basidioma. Slides were prepared with $3 \% \mathrm{KOH}$ for measurements. For spore size, additional information is provided: L, means spore length; W, means spore width; $\mathrm{Q}$, variation in the ratios of spore length/width. Slides were prepared with Melzer's reagent to observe amyloid or dextrinoid reactions of any structures. The absence of reaction with Melzer's reagent is indicated with "IKI-" (Ryvarden 2004). The presence of cyanophilic reaction was observed on preparations with Lactophenol cotton blue (CB). Color descriptions are based on the Methuen handbook (Kornerup and Wanscher 1978).

\section{DNA extraction, PCR amplification and sequencing}

Fragments from the basidiomata $(30-50 \mathrm{mg})$ were removed and placed in $1.5 \mathrm{ml}$ tubes and stored at -20 ${ }^{\circ} \mathrm{C}$ until DNA extraction was performed. The fragments were grinded with liquid nitrogen or homogenized in $2 \mathrm{ml}$ tubes containing $0.17 \mathrm{~g}$ of glass beads (425-600 $\mu \mathrm{m})$ and one $6.35 \mathrm{~mm}$ ceramic sphere using the FastPrep-24 ${ }^{\mathrm{TM}}$ 5G Instrument (MP Biomedicals). DNA was extracted using a modified method described in Goés-Neto et al. (2005) and Rodrigues et al. (2009). The reaction mix and parameters for PCR amplification of the ITS and LSU regions were as described by LimaJúnior et al. (2014), using the primer pairs ITS1-ITS4 or ITS4-ITS5 and LR0R-LR5, respectively (White et al. 1990; Lima-Júnior et al. 2014). Negative controls containing all components of the reaction mix, but exchanging DNA by water, were used in each procedure to detect possible contamination. The PCR products were purified either with ExoSAP-ITTM PCR Product Cleanup Reagent (Thermo Fisher Scientific, USA) or E.Z.N.A. ${ }^{\circledR}$ Cycle-Pure Kit (Omega Bio-tek ${ }^{\circledR}$ ) following the manufacturer's recommendations. Samples were Sanger sequenced at the Plataforma Tecnológica de Genômica e Expressão Gênica do Centro de Biociências, UFPE, Brazil, or sent to Stab Vida Lda (Madan Parque, Caparica, Portugal). Cycle sequencing was carried out with the same primers as amplification reactions (Moncalvo et al. 2000). All obtained sequences were deposited in NCBI GenBank (National Center for Biotechnology Information, Bethesda, MD, USA).

\section{Phylogenetic analyses}

The electropherograms were analyzed and edited using the 2.0 Staden Package software (Staden et al. 1998). Ready sequences were subjected to a BLASTn search in the NCBI GenBank (National Center for Biotechnology http://www.ncbi.nlm.nih.gov) to recover similar sequences. Reference sequences for datasets were chosen based on studies of Justo and Hibbett (2011), Floudas and Hibbett (2015), and Liu et al. (2018) in addition to those recovered from Genbank through BLASTn. These sequences were used in the dataset to study the phylogenetic relationships (Table 1). Each gene region was aligned with the MAFFT v.7 online interface (Katoh et al. 2017) using default settings (http://mafft.cbrc.jp/alignment/server), and then improved manually using MEGA 7 (Kumar et al. 2018), and combined to the form of a concatenated dataset.

The phylogenetic analyses and tree construction were performed using the maximum likelihood method (ML) and 
Table 1 Specimens used in this study. The sequences in bold were generated in this study

\begin{tabular}{|c|c|c|c|c|}
\hline \multirow[t]{2}{*}{ Species } & \multirow[t]{2}{*}{ Voucher } & \multirow[t]{2}{*}{ Country } & \multicolumn{2}{|c|}{ Gen Bank accession Number } \\
\hline & & & ITS & LSU \\
\hline Dentocorticium bicolor & FP-150666 & Belize & KY948710 & KY948878 \\
\hline Dentocorticium bicolor & He 2772 & China & MF626354 & MF626378 \\
\hline Dentocorticium bicolor & He 2757 & China & MF626355 & MF626379 \\
\hline Dentocorticium portoricence & He 2161 & USA & MF626356 & MF626380 \\
\hline Dentocorticium portoricence & He 2202 & USA & MF626357 & MF626381 \\
\hline Dentocorticium sulphurellum & T609 & Canada & JN165015 & JN164815 \\
\hline Dentocorticium taiwanianum & Wu 9907-1 (holotype) & China & MF626363 & MF626387 \\
\hline Dentocorticium taiwanianum & He 3383 & China & MF626361 & MF626388 \\
\hline Dentocorticium ussuricum & He 3322 & China & MF626360 & MF626384 \\
\hline Dentocorticium ussuricum & He 3294 & China & MF626359 & MF626383 \\
\hline Lopharia ayresii & He 2778 & China & MF626353 & MF626376 \\
\hline Lopharia ayresii & He 20120724 & China & MF626352 & MF626375 \\
\hline Lopharia aff. cinerascens & URM 93328 & Brazil & MK993643 & MK993637 \\
\hline Lopharia cinerascens & CBS 485.62 & USA & MH858220 & MH869821 \\
\hline Lopharia cinerascens & He2188 & USA & MF626350 & MF626373 \\
\hline Lopharia cinerascens & FP105043sp & USA & JN165019 & JN164813 \\
\hline Lopharia erubescens & URM 93246 & Brazil & MK993641 & MK993636 \\
\hline Lopharia erubescens & URM 93247 (type) & Brazil & MK993642 & - \\
\hline Lopharia mirabilis & Dai 5147 & China & MF626342 & MF626365 \\
\hline Lopharia mirabilis & Yuan 2532 & China & MF626343 & MF626366 \\
\hline Lopharia sinensis & He 2428 (holotype) & China & MF626347 & MF626370 \\
\hline Lopharia sinensis & He 2424 & China & MF626349 & MF626372 \\
\hline Phlebiopsis amethystea & URM 93248 & Brazil & MK993644 & MK993638 \\
\hline Phlebiopsis amethystea & URM 84741 & Brazil & MK993645 & MK993639 \\
\hline Phlebiopsis amethystea & URM 92985 & Brazil & MK993646 & MK993640 \\
\hline Phlebiopsis amethystea & URM 87790 & Brazil & MK993647 & MK995634 \\
\hline Phlebiopsis flavidoalba & FD-263 & USA & KP135402 & KP135271 \\
\hline Phlebiopsis flavidoalba & OM 17896 & USA & KX752607 & KX752607 \\
\hline Phlebiopsis flavidoalba & 103F9C-AM & Brazil & MG751231 & - \\
\hline Phlebiopsis flavidoalba & URM 87826 & Brazil & MK993648 & MK995635 \\
\hline Phlebiopsis gigantea & FP-70857-Sp & USA & KP135390 & KP135272 \\
\hline Phlebiopsis gigantea & CBS 935.70 & Germany & MH860011 & MH871798 \\
\hline Phlebiopsis yunnanensis & CLZhao 3990 & China & MH744141 & MH744143 \\
\hline Phlebiopsis yunnanensis & CLZhao 3958 & China & MH744140 & MH744142 \\
\hline Phlebiopsis crassa & SWFC001804 & China & MK811352 & - \\
\hline Phlebiopsiscrassa & JRH101909-1 & USA & MF773600 & - \\
\hline Phlebiopsis pilatii & no voucher & China & KY971603 & - \\
\hline Phlebiopsis ravenelii & CBS 411.50 & France & MH856691 & MH868208 \\
\hline Porostereum fulvum & LY:18496 & France & MG649453 & MG649455 \\
\hline Porostereum fulvum & LY:18491 & France & MG649452 & MG649454 \\
\hline Porostereum spadiceum & CBS 476.48 & France & MH856440 & MH867984 \\
\hline Porostereum spadiceum & KUC20080728-31 & Korea & JX463660 & JX463654 \\
\hline Stereum hirsutum & AFTOL-ID 492 & not mentioned & AY854063 & MH874407 \\
\hline
\end{tabular}

Bayesian algorithm (BA). The best-fist models of evolution were identified for the concatenated dataset from jModelTest (Posada 2008). The ML analyses were performed in MEGA 7 software and including 5000 bootstrap replicates. BA analyses were run in the TOPALi v2.5 (Milne et al. 2004) with $5 \times 10^{6}$ 
generation. Trees were visualized with MEGA 7 and the layouts were edited in the Microsoft PowerPoint.

\section{Results}

\section{Phylogenetic analyses}

Eight specimens were sequenced, generating both ITS and LSU sequences for each one. The combined dataset (ITS + LSU) included 43 and 40 sequences, respectively, with Stereum hirsutum (Willd.) Pers. as outgroup, and comprised 1572 characters including gaps, of which 678 belonged to ITS (1-678) and 894 to LSU (679-1572). The best models were $\mathrm{TRN}+\mathrm{G}+\mathrm{I}$ for ML analyses and $\mathrm{SYM}+\mathrm{G}$ for BA.

The results of the phylogenetic analyses generated from ML and BA showed quite similar tree topologies and small or no significant differences in the statistical support values. The ML tree topology with bootstrap support values (BS) and posterior probabilities (PP) from Bayesian inference of phylogeny (BI) is presented in Fig. 1. Two specimens clustered in a well-supported clade $(\mathrm{BS}=100 \% ; \mathrm{PP}=1.0)$ within the equally well-supported Lopharia s.s. clade (BS = 92\%; PP = 1.0 ), and confirm that those sequences belong to a new species, are described below. The specimens of Hjortstamia amethystea clustered in a strongly supported clade (BS = 98\%; $\mathrm{PP}=0.98)$ in the Phlebiopsis clade (BS $=100 \%$; $\mathrm{PP}=$ $1.0)$, thus the new combination Phlebiopsis amethystea, are proposed.

\section{Taxonomy}

Lopharia erubescens Xavier de Lima, sp. nov.

MycoBank: MB831392

Type: Brazil, State of Alagoas, Municipality of Quebrangulo, Biologial Reserve of Pedra Talhada, moist submontane broadleaf forest $9^{\circ} 15^{\prime} 00.7^{\prime \prime} \mathrm{S}, 36^{\circ} 25^{\prime} 38.3^{\prime \prime} \mathrm{W}$, on dead hardwood, leg. V. Xavier de Lima, 12 Oct 2018, VXL620 (holotype URM 93247).

Etymology: e.ru.bes.cens. N.L. neut. adj. erubescens means becoming red, in reference to the dextrinoid reaction of cystidia.

Basidioma resupinate, thin, tightly adnate, ceraceous when fresh and dry (Fig. 2a, b). Hymenophore smooth, white to pale yellow, in some parts may crack revealing the white subiculum or substrate. Margin thinning out, irregular, fibrillose, white. No reaction of any part of basidioma with $3 \% \mathrm{KOH}$.

Hyphal system monomitic, CB-. Hyphae with clamp connections, thin-walled. Subiculum thin to absent, composed mostly of interwoven and richly branched thin-walled hyphae, $1.5-4 \mu \mathrm{m}$ in diameter, with numerous small rhomboid crystals; thicker, straight hyphae with clamps at regular intervals often found, from which the subhymenium originates. Hyphae from the margin similar to the subiculum. Subhymenium composed of vertically oriented hyphae, compact, up to $150 \mu \mathrm{m}$ thick, hyphae agglutinated and difficult to discern in older parts, thinning out towards the margin where basidia and cystidia are loose or scattered, hyphae $2.5-3.5 \mu \mathrm{m}$ in diameter.

Cystidia as metuloids, numerous, arising from the subiculum and subhymenium, immersed or projecting above the hymenium, subulate to ventricose, hyaline, thick-walled, upper-half to two-thirds densely encrusted with hyaline crystals (Fig. 2 d), rarely naked, 35-53 $\times 8-12 \mu \mathrm{m}$ including crystals, $\mathrm{CB}+$, dextrinoid in Melzer's reagent in the lower portion (Fig. 2e)

Basidia clavate, $20-27 \times 3.5-6 \mu \mathrm{m}$, with a basal clamp, tetrasterigmate, sterigma up to $2.5 \mu \mathrm{m}$; basidioles cylindrical to distinctly clavate.

Basidiospores cylindrical, some slightly curved, hyaline, thin-walled, smooth, with visible guttulae, 5-6 $\times 1.5-2.5 \mu \mathrm{m}$, $\mathrm{Q}=2.5-3.3, \mathrm{~L}=5.3 \mu \mathrm{m}, \mathrm{W}=1.9 \mu \mathrm{m}, \mathrm{IKI}-$, CB- (Fig. 2h).

Remarks: The dextrinoid reaction in the metuloid bases is a distinctive feature that differentiates $L$. erubescens from the other species of the genus, as well as the smaller dimensions of basidia, cystidia and spore size and shape. The thin to almost absent subiculum and agglutinated subhymenium is also observed in L. ayresii, L. mirabilis, and L. resupinata; the latter species has numerous crystals in the subiculum (Liu et al. 2018). Lopharia erubescens subhymenium can be extremely compact in older parts, composed of agglutinated and collapsed cells, difficult to discern under the microscope, and towards the margin; the subhymenium becomes thinner and much less compact.

Ecology: Both specimens were found on 1.8-2.5 cm diameter logs, in advanced stage of decay.

Additional material examined: Brazil, the same locality as holotype, on dead hardwood, leg. V. Xavier de Lima, 12 Oct 2018, VXL619 (URM 93246).

Key to known neotropical Lopharia s.s. and Porostereum

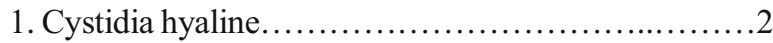

1. Cystidia pale yellow to brown..........................3

2. Cystidia with dextrinoid reaction; spores cylindrical, 5-6 $4 \mathrm{~m}$ long........................................ erubescens

2. Cystidia non-dextrinoid; spores ellipsoid, 10-16 $\mu \mathrm{m}$ long................................................ cinerascens 3. Hyphal system monomitic; spores 13-15 $\mu \mathrm{m}$ .Porostereum pilosiusculum

3. Hyphal system dimitic; spore 5-8 $\mu \mathrm{m} . . . \ldots \ldots \ldots \ldots \ldots . . . .4$ 4. Hymenophore lilaceous; most cystidia encrusted.... P. lilacinum

4. Hymenophore buff, ochraceous, brown; cystidia smooth or encrusted..................................... 5 
5. Cystidia smooth, large, up to $470 \mu \mathrm{m}$ long... .P. sharpianum

5. Cystidia encrusted, 35-60 $\mu \mathrm{m}$ long P. spadiceum

Phlebiopsis amethystea (Hjortstam \& Ryvarden) Chikowski \& C.R.S. Lira, comb. nov.

MycoBank: MB831393

Basionym: Porostereum amethysteum Hjortstam \& Ryvarden, Synopsis Fungorum 4: 27, 1990.

Type specimen described in Hjortstam and Ryvarden (1990), Ryvarden (2010) and Welden (2010).

Remarks: Phlebiopsis amethystea is easily recognized by the effused-reflexed basidioma, purplish colors of the smooth hymenophore, and brownish hyphae. It differs from the other species of the genus by the dark brown cystidia. It is morphologically very similar to Ph. crassa, but can be distinguished by several characteristics: (1) context is darker than hymenial surface in $P h$. amethystea (Fig. 3d), whereas in Ph. crassa the context is paler (Fig. 4b) (Hjortstam and Ryvarden 1990); (2) hymenophore color may vary, but it has consistently purple hues in the dried specimens of $P h$. amethystea analyzed (Fig. 3a, b, c d), while Ph. crassa presents brownish and reddish tints (Fig. 4a, b); (3) Ph. amethystea has three types of cystidia, of hymenial, and contextual origin, whereas only one type of cystidia originating from the context is present in Ph. crassa; (4) contextual metuloids in $P h$.
Fig. 1 Phylogenetic reconstruction for

Dentocorticium, Lopharia, Phlebiopsis, and Porostereum inferred from a combined dataset of ITS and nLSU. Parsimony bootstrap generated by ML (higher than 50\%) and BA posterior probabilities (higher than 0.70 ) are shown along the branches

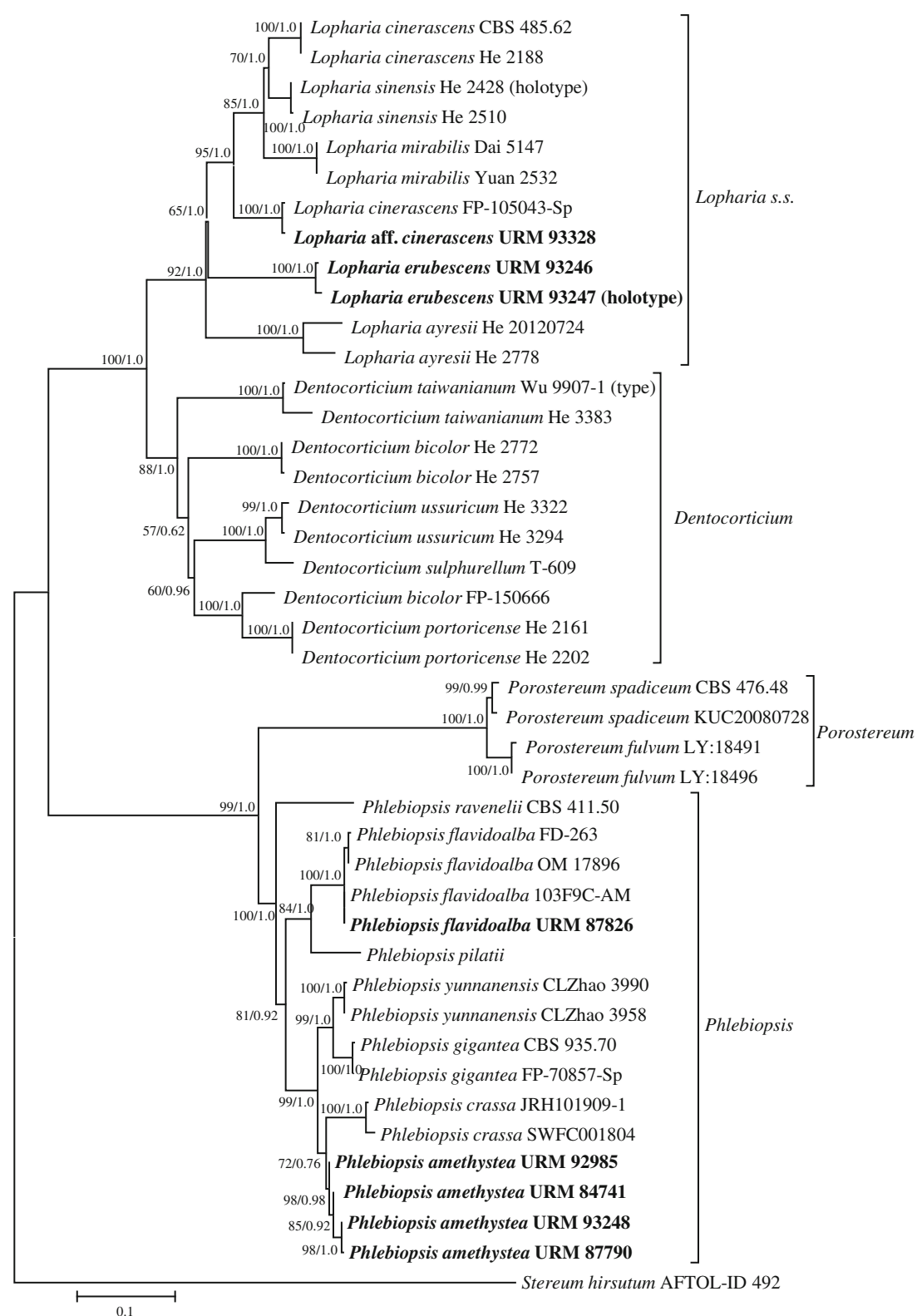


Fig. 2 Lopharia erubescens sp. nov. a, b Macromorphological aspect in field. a Voucher URM 93247 (holotype). b Voucher URM 93246. c Vertical section showing the basidioma (B) and the substrate (S). d Cystidia of subhymenial origin, in $\mathrm{KOH} 3 \%$. e Dextrinoid reaction at the cystidial base, in Melzer's reagent. $\mathbf{f}$ Basidia. Red arrow pointing to the basal clamp. $\mathbf{g}$ Subiculum. h Spores in Cotton Blue Lactophenol. Images $\mathbf{c}, \mathbf{d}, \mathbf{e}$, $\mathbf{f}, \mathbf{g}$, and $\mathbf{h}$ are from the holotype. Bars: $\mathbf{a}, \mathbf{b}=1 \mathrm{~cm} ; \mathbf{c}=100 \mu \mathrm{m} ; \mathbf{d}$, $\mathbf{e}=20 \mu \mathrm{m} ; \mathbf{f}, \mathbf{g}, \mathbf{h}=10 \mu \mathrm{m}$
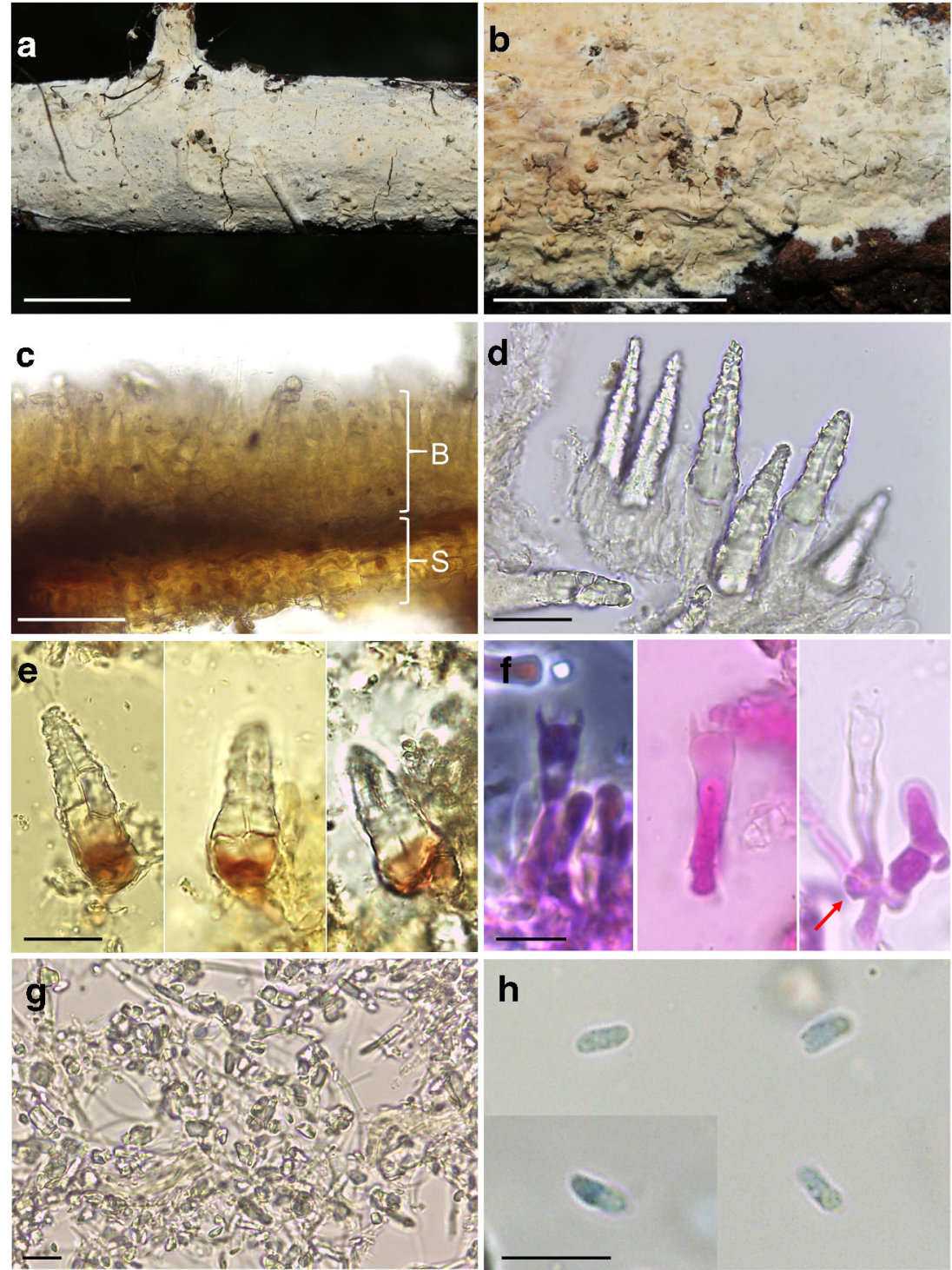

h

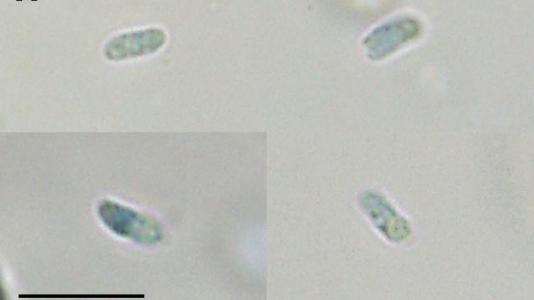

amethystea are brown and dark brown, bear persistent coarse crystals and are scattered in the basidioma (Fig. $3 \mathrm{~g}$ ), whereas in Ph. crassa metuloids are very abundant, yellowish, and pale brown, and bear much finer crystals that easily dissolve and detaches in microscopic preparations (Fig. 4c, d, e).

Material examined: Phlebiopsis amethystea: Brazil: Alagoas, Quebrangulo, Biological Reserve of Pedra Talhada, $9^{\circ} 15^{\prime} 01$ " S, 36 $26^{\circ} 38^{\prime \prime} \mathrm{W}, 758 \mathrm{~m}$ asl., leg. V. Xavier de Lima, 9 Sep. 2018, VXL555 (URM 93252); leg. V.R.T. Oliveira, 19 Jul 2018 (URM 92583); Ceará, Missão Velha, $7^{\circ} 14^{\prime} 58^{\prime \prime} \mathrm{S}, 39^{\circ} 08^{\prime} 35^{\prime \prime} \mathrm{W}$, leg. T.B. Gibertoni, $28 \mathrm{Mar}$ 2011, TBG125 (URM 83375); Taianguá, 343'48”S, 40'59'33”O leg. C.R.S. Lira, 2012 (URM 84741); Mato Grosso do Sul, Campo Grande, 20³0'28" S, 54³7'02" W, leg. D.C. dos Santos (URM 92985), Pará, Maracanã,
Maiandeua Island, 0³5'42" S, 47³4'54" W, leg. E. L. Campos, Jul 1998 (URM 76945), leg. E.L. Campos, May 1999 (URM 76945), Paraíba, Areia, Mata do Pau Ferro, 6 $57^{\prime} 47^{\prime \prime}$ S, $35^{\circ} 41^{\prime} 30^{\prime \prime} \mathrm{W}$, leg. C.R.S. Lira 9, Nov. 2010 (URM 83070), leg. C.R.S. Lira, 24 Aug 2012, CL307 (URM 87790), Pernambuco, Recife, Dois Irmãos Zoo Botanical Park, $8^{\circ} 00^{\prime} 59^{\prime \prime} \mathrm{S}, 35^{\circ} 35^{\prime} 09^{\prime \prime} \mathrm{W}$, leg. M. Rajchenberg, 5 Aug 2009, MJ-D1 (URM 83789), Triunfo, Carro Quebrado Farm, 751'17' S, 38 06'06” W, 700-1100 m asl., leg. C.R.S. Lira, 12 Jul 2012, CL161 (URM 93248), Piaui, Caracol, Serra das Confusões, $9^{\circ} 16^{\prime} 42^{\prime \prime}$ S, 43ำ $19^{\prime} 48^{\prime \prime}$ W, A. Gomes-Silva, 28 Mar 2011, AC184 (URM 83376). Phlebiopsis crassa: USA, NC, Dare County, Roanoke Island, leg. unknown, 17 Aug 1957, (URM 13206); MD, Anne Arundel County, Herald Harbor, on Ilex opaca, leg. C.R. Benjamin, 30 Jul 1962 (URM 29832). 
Fig. 3 Phlebiopsis amethystea. a Pilear surface and general aspect of the basidioma in field. Voucher URM 93252. b Hymenial surface in field. Voucher URM 93252. c, d Dried specimens URM 76944 and URM 87790. e Metuloid cystidia of hymenial origin (URM 76944). f Thick-walled hyphae of context and tomentum (URM 76944). g Metuloid cystidia of contextual origin (URM 76944). Bars: $\mathbf{a}, \mathbf{b}, \mathbf{c}, \mathbf{d}=2 \mathrm{~cm} ; \mathbf{e}, \mathbf{f}, \mathbf{g}=20$ $\mu \mathrm{m}$
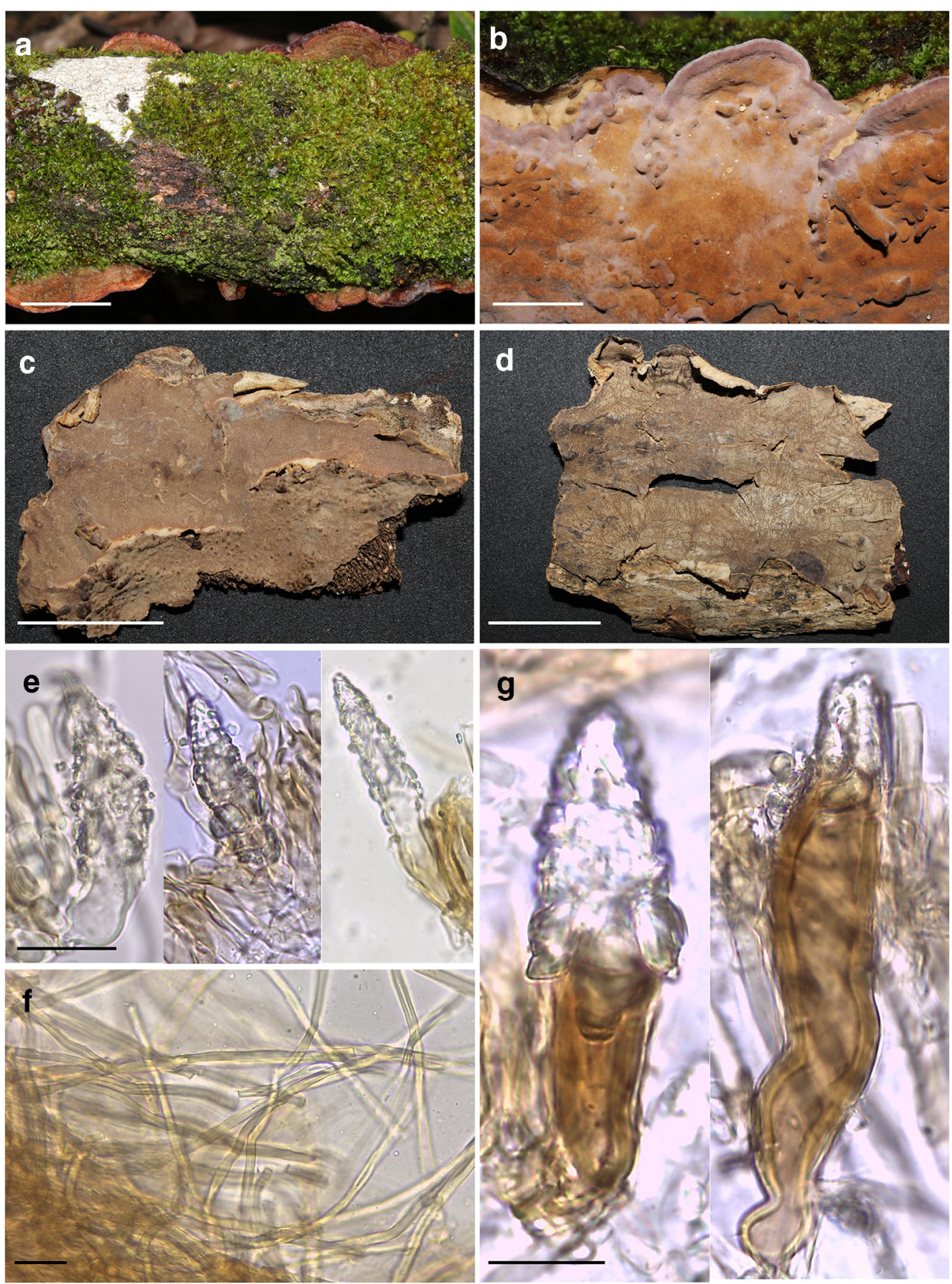

Key to known neotropical Phlebiopsis and allied species

1. Dimitic with dendroid binding hyphae, cystidia absent or undifferentiated. ..Hjortstamia mexicana 1. Monomitic or dimitic with typical skeletal hyphae, cystidia smooth or encrusted............................ 2 2. Cystidia pale yellow to dark brown..................... 3

2. Cystidia hyaline..................................7 3. Basidioma resupinate, hymenophore grayish, monomitic..........................................4 3. Basidioma resupinate to effused-reflexed, hymenophore with purple, violet and reddish tints, dimitic, cystidia predominantly encrusted with crystals.....

.6

4. Cystidia smooth and large, up to $120 \mu \mathrm{m}$ long, subiculum distinct basidia 22-25 $\mu \mathrm{m}$ long..............

Hjortstamia novae-granata 4. Cystidia encrusted, 22-51 $\mu \mathrm{m}$ long, subiculum very thin to indistinct, basidia $14-22 \mu \mathrm{m}$ long ...................5 5. Cystidia 31-51 $\mu \mathrm{m}$ long, subiculum difficult to discern from subhymeniu.................Phaeophlebiopsis ignerii 5. Cystidia 22-38 $\mu \mathrm{m}$ long, subiculum very thin, brown.....................Phaeophlebiopsis caribbeana 

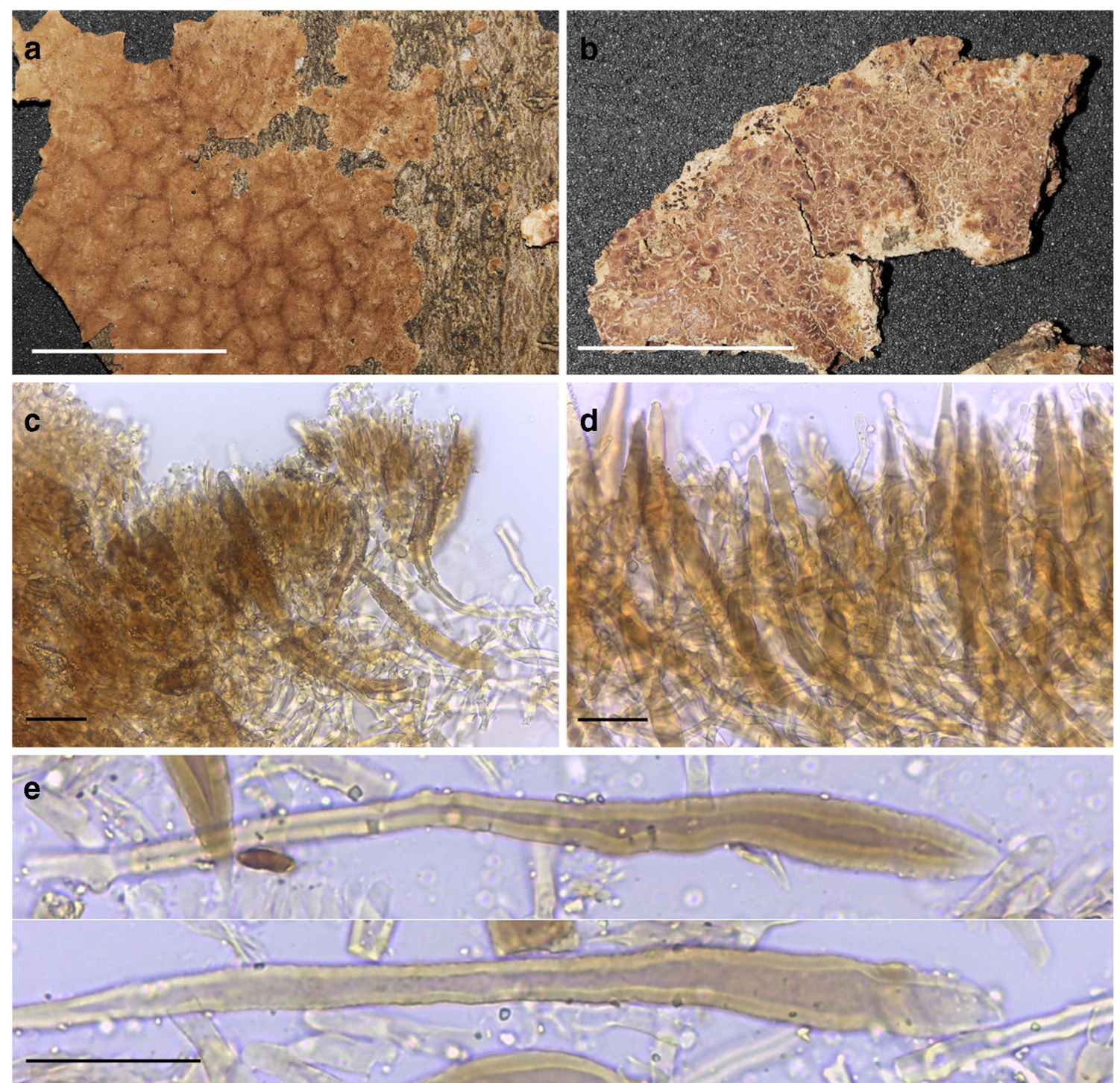

Fig. 4 Phlebiopsis crassa. a, b Dried specimens URM 13206 and URM 29832. c, d Vertical sections of the hymenophore, showing the contextual origin of cystidia (URM 13206). e Cystidia (URM 13206). Bars: $\mathbf{a}, \mathbf{b}=2 \mathrm{~cm} ; \mathbf{c}, \mathbf{d}, \mathbf{e}=20 \mu \mathrm{m}$

6. Cystidia of up to three type, contextual metuloids brown to dark brown.................Phlebiopsis amethystea 6. Only contextual metuloids present, hyaline to pale brown...................................Phlebiopsis crassa 7. Hymenophore whitish, gray to buff, cystidia often with adventitious sept.........................Phlebiopsis gigantea 7. Hymenophore cream to brown, cystidia non-septate............................................. 8

8. Basidioma effused-reflexed to distinctly pileate, dimitic..............................Phlebiopsis papyrina

8. Basidioma resupinate, monomitic.....................9

9. Subiculum thin to absent, spores $4-5 \mu \mathrm{m}$ long..................................Phlebiopsis ravenelii 9. Subiculum distinct, spores 5-7.5 $\mu \mathrm{m}$ long
10. Basidia 15-20 $\mu \mathrm{m}$ long, cystidia 7-10 $\mu \mathrm{m}$ wide...............................Phlebiopsis galochroa 10. Basidia 22-30 $\mu \mathrm{m}$ long, cystidia 10-18 $\mu \mathrm{m}$ wide. Phlebiopsis flavidoalba

\section{Discussion}

The main morphological characteristics of Lopharia erubescens are in accordance with what is known for the genus, such as the clavate basidia, presence of metuloids, clamped hyphae, and IKI-, CB- smooth spores. However, several features of L. erubescens diverge from typical species of the genus, like the dextrinoid cystidia, size of basidia, and size and shape of 
spores. Among the corticioid basidiomycetes, Dextrinocystis Gilb. \& M. Blackw. and Litschauerella Oberw. (Trechisporales) also have dextrinoid cystidia, but they are thick-walled and multi-rooted, distinct from the typical metuloids observed in Lopharia. In the most recent emendation of Lopharia, Liu et al. (2018) indicated the basidia longer than $50 \mu \mathrm{m}$ as a feature of the genus; however, L. erubescens has basidia around $25 \mu \mathrm{m}$ long and spores narrower than all species of Lopharia s.s.

An additional specimen of Lopharia (URM 93328), which was found in northeast Brazil (Paraíba) in our phylogeny, was found to be of the same clade as L. cinerascens (Schwein.) G. Cunn. from the southern USA (MS, FP-105043). The holotype of $L$. cinerascens was found in the northern part of the USA (PA), as well as specimens He2188 (WI) and CBS 485.62 (NY). Liu et al. (2018) suggested that specimens from the north of THE USA belong to L. cinerascens s.s., whereas the specimens found in the southern states of the USA may belong to a different species. Thus, it is likely that L. cinerascens s.s. is restricted to temperate climates, whereas morphologically similar specimens from subtropical and tropical climates represent a different species. Unfortunately, the specimen PB359 is sterile, and the dry specimen of the available FP-105043 culture is lost (Beatriz Ortiz-Santana, personal communication), making it such that the formal description of a new species is not advised.

Phlebiopsis amethystea, previously placed in Hjortstamia, is phylogenetically a member of Phlebiopsis, but the morphological affinities are vague. Phlebiopsis was introduced to accommodate Thelephora gigantea Fr. (Jülich 1978), but differs from $P h$. amethystea and similar species, such as Ph. crassa, in several aspects, agglutination of hymenial elements, construction of subiculum, consistency of dried specimens and hyphae color. The morphological limits of Phlebiopsis are not clear (Eriksson et al. 1981), and recent phylogenetic studies (Floudas and Hibbett 2015; Miettinen et al. 2016) show that there is no obvious differentiation between lineages of Phanerochaete s.l. (Phanerochaete s.s., Phlebiopsis, Phaeophlebiopsis, Scopuloides and others). Phlebiopsis amethystea is one of the most common stereoid fungi in Brazil, but seems to be rare elsewhere. Outside the type locality (Brazil), it was also recorded in Ecuador (Welden 2010) and Spain (Canary Islands; Beltrán-Tejera et al. 2013). The morphological similarities with $P h$. crassa, a widespread species, may cause misidentification, and the geographical distribution of $P$. amethystea is apparently much wider. When the species was firstly described (Hjortstam and Ryvarden 1990), and even later (Ryvarden 2010; Welden 2010), only the type specimen and a few additional collections were studied.

Phlebiopsis amethystea was initially described as a species of Porostereum (Hjortstam and Ryvarden 1990), which was differentiated from Lopharia mostly by the smaller spores, and then further segregated into Hjortstamia because of the lack of clamp connections (Boidin and Gilles 2003). Of the 19 names of Porostereum listed in the Index Fungorum database, only four are now accepted in the genus. The type species of the genus, $P$. phellodendri Pilát, was not yet sequenced, making the concept of Porostereum somewhat unclear. However, Hjortstam and Ryvarden (1990) treated $P$. phellodendri Pilát as heterotypic synonym of Thelephora spadicea Pers., proposing a new combination $P$. spadiceum (Pers.) Hjortstam \& Ryvarden, placed in the Bjerkandera clade (Phanerochaetaceae; Miettinen et al. 2016). Morphological limits between Porostereum and Lopharia are not clear, as both have clamped hyphae, mono-dimitic hyphal systems, and hyaline to brown thick-walled cystidia. With the exception of the simple septate species, which are now mostly combined in Phlebiopsis, we decided to keep the other Lopharia s.l. listed in Welden's monograph in the key. Lopharia rimosissima is not included in the key, as basidia and spore were not described nor found in the type specimen (Welden 2010). With this, we concluded that consistent identification is not possible.

In summary, there is no morphological feature for reliably differentiating the genera discussed here. Simple septate species are grouped in Hjortstamia, Phaeophlebiopsis, and Phlebiopsis. Besides generative hyphae with simple septa, this group is characterized by the mono-dimitic hyphal system, presence of metuloid cystidia, clavate basidia, and ellipsoid, CB-, IKI- spores. Species with clamped hyphae are in Lopharia and Porostereum, but they share all other features with the previous group. There are several species for which phylogenetically important DNA sequences are not available, especially those with tropical distribution, which in the future can improve our understanding of this group.

Funding information The authors would like to thank Diogo Careli dos Santos for the donation of the collection, the Herbário Pe. Camille Torrend (URM) for the loan of the exsiccates, the Programa de Pós Graduação em Biologia de Fungos (UFPE, Brazil), Conselho Nacional de Desenvolvimento Científico e Tecnológico (CNPq; grant SISBIOTA (563342/2010-2), PPBio Semi-Árido (457476/2012-5), PROTAX (562106/2010-3), Universal (472792/2011-3), PQ (307601/2015-3)), Coordenação de Aperfeiçoamento de Pesquisa e Ensino Superior (CAPES; grant Capes-SIU 008/13) and Fundação de Amparo à Ciência e Tecnologia do Estado de Pernambuco (FACEPE; grant ATP-0021-2.03/ 18, APQ-0788-2.03/12) for the financial support. CAPES is also acknowledged for the master scholarship of RSC and $\mathrm{PhD}$ scholarship of CRSL, and FACEPE for the PhD scholarship of RSC and post-doctorate scholarship of CRSL and VXL. We also would like to thank Nordesta Reforestation \& Education for the support in the field work performed at the Biological Reserve of Pedra Talhada. This study was also partially supported by the Portuguese Foundation for Science and Technology (FCT) under the scope of the strategic funding of the UID/BIO/04469/ 2019 unit and the BioTecNorte operation (NORTE-01-0145-FEDER000004) funded by the European Regional Development Fund under the scope of Norte2020-Programa Operacional Regional do Norte.

\section{References}

Beltrán-Tejera E, Rodríguez-Armas JL, Telleria MT, Dueñas M, Melo I, Díaz-Armas MJ, Salcedo I, Cardoso J (2013) Corticioid fungi from 
arid and semi-arid zones of the Canary Islands (Spain). Additional data. 2. Mycotaxon 123:492

Bernicchia A, Gorjón SP (2010) Corticiaceae s.l., Fungi Europaei 12. Ed. Candusso, Italy

Boidin J, Gilles G (2002) À propos du genre Lopharia sensu lato (Basidiomycètes, Aphyllophorales). Bulletin de la Société Mycologique de France 118(2):91-115

Burt EA (1920) The Thelephoraceae of North America. XII Stereum. Ann Mo Bot Gard 7:81-249

Chen C-C, Wu S-H, Chen C-Y (2018) Four species of polyporoid fungi newly recorded from Taiwan. Mycotaxon 133(1):45-54. https://doi. org/10.5248/133.45

Eriksson J, Hjortstam K, Ryvarden L (1981) The Corticiaceae of North Europe 6: Phlebia-Sarcodontia. Fungiflora, Oslo

Floudas D, Hibbett DS (2015) Revisiting the taxonomy of Phanerochaete (Polyporales, Basidiomycota) using four gene dataset and extensive ITS sampling. Fungal Biol 119:679-719

Goés-Neto A, Loguercio-Leite C, Guerrero RT (2005) DNA extraction from frozen field-collected and dehydrated herbarium fungal basidiomata: performance of SDS and CTAB-based methods. Biotemas 18:19-32

Hibbett DS, Bauer R, Binder M, Giachini AJ, Hosaka K, Justo A, Larsson E, Larsson KH, Lawrey JD, Miettinen O, Nagy LG, Nilsson RH, Weiss M, Thorn RG (2014) Agaricomycetes. In: McLaughlin DJ, Spatafora JW (eds) The Mycota VII. Systematics and evolution, 2nd edn. Springer-Verlang, Berlin

Hjortstam K, Ryvarden L (1990) Lopharia and Porostereum (Corticiaceae). Synopsis Fungorum 4. Fungiflora, Oslo

Jülich W (1978) Studies in resupinate Basidiomycetes - V. Persoonia 10: $137-140$

Justo A, Hibbett D (2011) Phylogenetic classification of Trametes (Basidiomycota, Polyporales) based on a five-marker dataset. Taxon 60(6):1567-1583

Katoh K, Rozewicki J, Yamada KD (2017) MAFFT online service: multiple sequence alignment, interactive sequence choice and visualization. Brief Bioinform. https://doi.org/10.1093/bib/bbx108

Kornerup A, Wanscher JH (1978) Methuen handbook of colour, 3rd edn, London

Kumar S, Stecher G, Li M, Knyaz C, Tamura K (2018) MEGA X: molecular evolutionary genetics analysis across computing platforms. Mol Biol Evol 35:1547-1549. https://doi.org/10.1093/molbev/ msy096

Lima-Júnior N, Gibertoni TB, Malosso E (2014) Delimitation of some neotropical laccate Ganoderma (Ganodermataceae): molecular phylogeny and morphology. Rev Biol Trop 62:1197-1208
Liu SL, Nakasone KK, Wu SH, He SH, Dai YC (2018) Taxonomy and phylogeny of Lopharia s.s., Dendrodontia, Dentocorticium and Fuscocerrena (Basidiomycota, Polyporales). MycoKeys 32:25-48. https://doi.org/10.3897/mycokeys.32.23641

Miettinen O, Spirin V, Vlasák J, Rivoire B, Stenroos S, Hibbet D (2016) Polypores and genus concept in Phanerochaetaceae (Polyporales, Basidiomycota). MycoKeys 17:1-46. https://doi.org/10.3897/ mycokeys.17.10153

Miller SL, Larsson E, Larsson KH, Verbeken A, Nuytinck J (2006) Perspectives in the new Russulales. Mycologia 28:960-970. https://doi.org/10.1080/15572536.2006.11832625

Milne I, Wright F, Rowe G, Marshall DF, Husmeier D, McGuire G (2004) TOPALi: software for automatic identification of recombinant sequences within DNA multiple alignments. Bioinformatics 20:18061807. https://doi.org/10.1093/bioinformatics/bth155

Moncalvo JM, Lutzoni FM, Rehner SA, Johnson J, Vilgalys R (2000) Phylogenetic Relationships of Agaric Fungi Based on Nuclear Large Subunit Ribosomal DNA Sequences. Systematic Biology 49(2):278-305

Posada D (2008) jModelTest: phylogenetic model averaging. Mol Biol Evol 25:1253-1256. https://doi.org/10.1093/molbev/msn083

Rodrigues P, Venâncio A, Kozakiewicz Z, Lima N (2009) A polyphasic approach to the identification of aflatoxigenic and non-aflatoxigenic strains of Aspergillus section Flavi isolated from Portuguese almonds. Int J Food Microbiol 129:187-193

Ryvarden L (2004) Neotropical polypores. Part 1. Synopsis Fungorum 19. Fungiflora, Oslo

Ryvarden L (2010) Stereoid fungi of America. Synopsis Fungorum 28. Fungiflora, Oslo

Staden R, Beal KF, Bonfield JK (1998) The staden package. Computer methods in molecular biology. Bioinform Methods Protoc 132:115130. https://doi.org/10.1385/1-59259-192-2:115

Welden AL (2010) Flora Neotropica, Vol. 106, Stereum s.l. New York Botanical Garden Press, New York

White TJ, Bruns T, Lee S, Taylor JW (1990) Amplification and direct sequencing of ribosomal RNA genes for phylogenetics. In: Innis MA, Gelfand DH, Sninsky JJ, White TJ (eds) PCR protocols: a guide to methods and applications. Academic Press, New York

Publisher's note Springer Nature remains neutral with regard to jurisdictional claims in published maps and institutional affiliations. 